measurements on antisera showed that the 'top component' of turnip yellow mossic virus, which has no nucleic acid, was much less efficient in stimulating antibody production than the 'bottom com. ponent' which is the nucleoprotein. In Chapter 8 the methods for estimating virus concentration are discussed, the precipitation reaction providing a rapid and convenient means towards this end. The specificity of the reaction allows virus to be estimated in the presence not only of plant impurities but also of unrelated viruses. In Chapter 9 the cross-absorption procedure is dealt with which can be used for estimating degrees of relationship between viruses, and in Chapters 10 and 11 experiments with mixtures of viruses and strains of viruses, and the causes of failure to obtain positive serological tests, are discussed. With regard to the last point, antisera have been prepared for about thirty plant viruses or groups of virus strains, but there are still 200 or more viruses to which serological methods have not yet been applied. In some cases repeated attempts to obtain antisera have resulted in failure; this may be in part due to lack of concentration of the virus, so that new methods of virus concentration may have to be devised. Then, of course, a large number of viruses are not mechanically transmissible and this greatly complicates the study of their serology.

This book is a valuable contribution to the study of plant viruses, and should be read by all plant virologists and by immunologists in general. The different procedures and their pitfalls are carefully and lucidly explained, and the illustrations and tables are excellent. The electron micrograph, in the frontispiece, shows dramatically how, in a mixture of viruses, the antiserum aggregates only the virus against which it was prepared. KENNETH M. SMrTH

\section{THEORY OF INSTRUMENTATION}

\section{Instrument Technology}

By E. B. Jones. Vol. 2: Analysis Instruments. Pp. $\mathrm{xi}+208$. 40s. Vol. 3 : Telemetering and Automatic Control. Pp. $\mathrm{x}+198$. 40s. (London: Butterworths Scientific Publications, 1956-57.)

$\mathrm{T}$ is always a pleasure to read clear prose, and quite $L$ apart from the technical merits of these volumes, one is impressed by their lucidity. In these volumes, as in their predecessor, the author chooses as his audience the instrument mechanics of industry. Anyone interested in his subject can sympathize with the author in his task of selecting material and restricting explanations in a field where to-day's success may be to-morrow's museum exhibit. Mr. E. B. Jones is to be congratulated on providing a theoretical background to efficient instrument use and maintenance, even if it is possible to differ from the publisher's announcement which rather suggeste the work is a maintenance guide. Obviously, nothing can replace the manufacturer's manual and still remain of general interest.

The second volume describes the principles and applications of measurements based on the composition of fluid streams or samples, and thus continues the treatment of pressure, level, and temperature measurement which was covered in Vol. 1. In this volume the very clear diagrams, and the short accounts of physical and chemical principles, are very attractive. The third volume attempts to show the application of automatic control to processes where variables are measured by the means examined in earlier volumes. In the discussion on telemetering, and especially of automatic control, all material appears to have been tested by the yardstick of usefulness, so that a well-grounded, but general, treatment results.

One can recommend this book for the training of instrument mechanics, since the level of knowledge that it will provide as adjuncts to the practical skills of installation, maintenance and 'trouble-shooting' can only result in a more intelligent use of instruments and automatic control devices. $\quad$ T. K. Ross

\section{ELECTRONICS DIGEST}

Handbook of Industrial Electronic Control Circuits By John Markus and Vin Zeluff. Pp. xv +352 . (London: MeGraw-Hill Publishing Company, Ltd., 1956.) $66 s$.

\section{The Cathode Ray Oscilloscope}

Circuitry and Practical Applications. By J. Czech. Pp. xii +340. (Eindhoven: N. V. Philips' Glooilampenfalbrieken; London: Cleaver-Hume Press, Ltd., 1957.) 57s. $6 d$.

A CRITICAL survey of some aspect of technology $A$ is no mean task when undertaken by an individual author, if his book is to be ressonably up to date at the time that it appears. There are other and complementary ways of presenting accounts of current practice, either through collected digests of articles that have appeared in the technical periodicals, or from the collective experience of a company specializing in a particular field.

The book by Markus and Zeluff might be described as 'articles of lasting interest, skilfully digested' from the well-known journal Electronics. Some 350 articles that appeared during 1948-55 are included in a volume weighing $3 \mathrm{lb}$., a worth-while reduction from the $6 \mathrm{ft}$. shelf and $200 \mathrm{lb}$. of the original magazines.

Czech's book for users of the cathode ray oscilloscope is translated from the German, and is one of the extensive series of Philips's technical and scientific publications. Like many titles in the series, it is closely related to the experience and products of that Company.

While both books lack the critical approach to first principles so valuable to the advanced designers of equipment, they will be helpful to the wider circle of technicians interested in particular applications. The selection from Electronics has been classified under such headings as amplifier circuits, capacitance control, counting circuits, messuring circuits, metal detectors, motor control, oscillators, photoelectric controls, temperature control, timing, power supply and transistor circuits. A rather full index has been added, and provides a useful cross-reference between articles containing related material; the original reference is given in each case. As the title suggests, the emphasis is upon industrial control applications, written at the consistently practical level of the journal in which they appeared.

The user of cathode ray oscillographs will find the second book helpful, particularly because of the large number of oscillograms used as illustrations. It is not recommended as a 'first reader' on the subject, but is valuable for being written from a point of view different from the several English stendard works. Its origin is most evident in the bibliography, and in the illustrations of instruments and circuits of one 